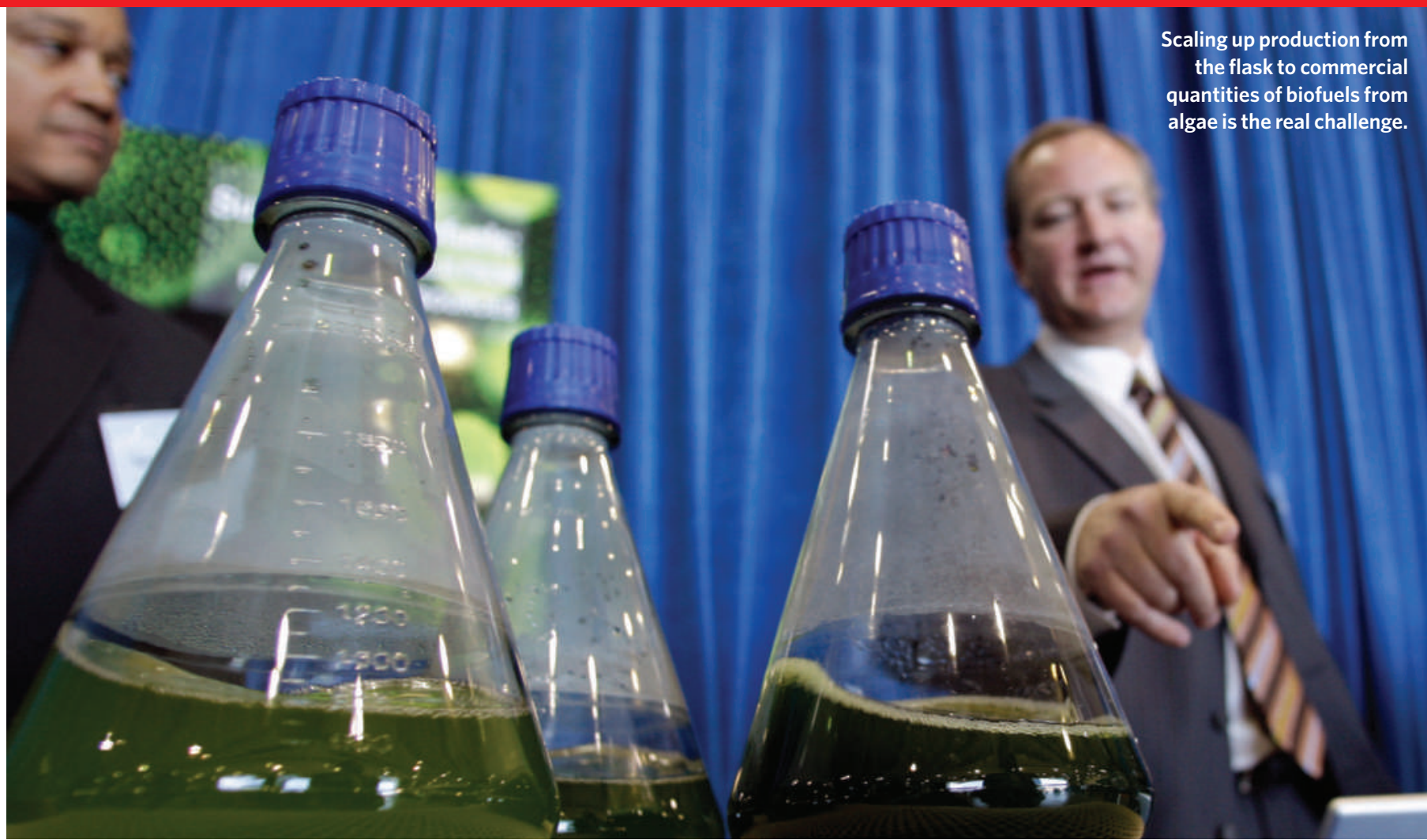

\title{
Gold rush for algae
}

\section{The second of four weekly articles on biofuels describes how oil giants and others are placing their bets on algae.}

\section{THE BUSINESS OF BIOFUELS}

No longer lowly pond scum, algae have rocketed in status to what some say is the most promising 'green' fuel source of the future. With the likes of Bill Gates, the US military and ExxonMobil trumpeting their potential, "it's hard to find someone on the sidewalk in New York who hasn't heard about the idea of using algae for energy," says Harrison Dillon, president and chief technology officer of Solazyme, a biotechnology company in South San Francisco, California. The company this month signed an \$8.5-million deal to produce commercial quantities of algal fuel for the US Navy.

Algae's photosynthetic cells produce an oily goo, including various oils and ethanol, that can be converted into advanced biofuels. Since 2007, more than $\$ 1$ billion has been injected into algae-to-energy research and development, says Will Thurmond, president of Emerging Markets Online, an energy consulting firm in Houston, Texas. "The validation is good for us," says Tim Zenk, vice-president of corporate affairs at Sapphire Energy, an algal-biotech company based in San Diego, California, that has investment backing from philanthropist Gates.

Algae have several key traits that make them a desirable energy source. They can be grown on non-agricultural land in a fraction of the area required by conventional oil crops such as maize (corn), soybean and palm. In addition, algae capture carbon dioxide and can thrive in domestic waste water or salt water. But experts warn that there are still high hurdles to overcome before algal biofuels can compete economically with conventional fossil fuels. Challenges include finding strains of algae that reliably produce high yields, keeping contamination at bay, developing costeffective growth chambers and efficiently harvesting oil from the cells. "In the end, it's all going to come down to economics and what it's going to cost to produce this algal oil on a large, commercial scale on a dollar-pergallon basis," says Al Darzins,

who leads the algal biofuels programme at the National Renewable Energy Laboratory (NREL) in Golden, Colorado.

In 2007, the United States consumed some 150 billion litres of diesel. Algal-biofuel companies may be able to produce millions of litres of oil in the next few years, but probably not billions, says Darzins: "We don't have the infrastructure."

To date, the biggest investment boon for algae has come from oil giant ExxonMobil, which in July announced that it will invest $\$ 600$ million over five to six years in a partnership with Synthetic Genomics, a company in La Jolla,
California, co-founded by genomics pioneer J. Craig Venter. ExxonMobil has said that its investment is contingent on Synthetic Genomics achieving certain milestones, and that if their efforts are successful, it expects to spend billions more on final development and early commercialization of algal biofuels. Synthetic Genomics is in the early stages of its venture, but the company maintains that it has engineered algal cells that can directly secrete hydrocarbons in pure form, in contrast to the standard process of splitting the cells open to harvest their oils.

Other major oil players that have entered the algal arena include Chevron, which partnered the NREL in 2007 and helped to restart, with an undisclosed amount, a research programme that had been shuttered since 1996. Chevron also announced a deal with Solazyme in January 2008, although the partners will offer only vague details about the nature of their collaboration. And this August, $\mathrm{BP}$ announced a \$10-million algal investment in Martek Biosciences, a nutritional-science company based in Columbia, Maryland.

In addition, Dow Chemical Company is backing Algenol Biofuels, a company in Bonita Springs, Florida, that specializes in ethanol production from algae, in its quest for a \$25-million grant from the US Department of Energy. 
If Algenol gets the grant, it will construct a pilot plant with Dow at Dow's manufacturing site in Freeport, Texas, with the goal of capturing industrial carbon dioxide and producing algaderived ethanol to generate ethylene, a building block for plastics.

Meanwhile, Sapphire Energy has garnered more than $\$ 100$ million from bigwig investors, including Gates's Cascade Investments and the Rockefeller family's venture-capital firm Venrock. Sapphire is using genetic engineering to boost several algal traits, including improved protection from predators and lowcost harvestability. It is also working to genetically manipulate the algae to produce oils that are nearly identical to crude oil as extracted from the ground.

And Solazyme's contract with the Navy is the first contract anywhere to manufacture commercial-scale quantities of next-generation biofuels. The contract requires that Solazyme deliver some 75,000 litres of F-76 renewable fuel, which is similar in composition to diesel fuel, over the next year. "This really raises the bar in what constitutes a true production capability versus an interesting research direction," says Dillon.

Still, many challenges remain. In May GreenFuel Technologies, a front-runner on the algal scene that had amassed some $\$ 70$ million in investments since 2001, announced that it was closing down. Sam Jaffe, an energy analyst with IDC Energy Insights, a research and analysis firm based in Framingham, Massachusetts, says that GreenFuel pursued too many different technologies, including expensive greenhouses to control algal growth conditions. "Growing algae is easy," says Jaffe. "Growing it as a business and making money off of it is about getting the costs down."

One of the biggest challenges is to reproduce laboratory conditions on a large scale. In the lab, it can be easier to control algal growth and to find strains that produce copious amounts of oil. "But it's a totally different story when you take this organism that behaves well in the laboratory and you put it in acres' worth of outdoor ponds," says Darzins. For this reason, some companies have opted to grow their algae in enclosed 'bioreactors'. But the costs of building bioreactors can be prohibitively expensive. The algae community is "still torn" between open ponds and closed bioreactors, Darzins says.

With so much enthusiasm and investor interest in algal technology, new companies have sprung up almost overnight. Some experts say that because much of the science behind these technologies is not peer reviewed and is done through privately held companies, it can be difficult to gauge their progress. "On the one hand you get their hype, and on the other hand they're guarding everything so closely that you can't evaluate it," says Martha Groom, a conservation biologist at the University of Washington in Bothell. "I find that fairly frustrating."

Experts say that a few companies have made questionable assertions about how much fuel they can reap from their algae. "Unfortunately, a lot of people tout these technologies and yet don't have the production data to back it up," says Doug Henston, chief executive of Solix Biofuels, a renewable-energy company based in Fort Collins, Colorado, that opened an algal oil-production demonstration facility in July at a coal-bed methane plant in southwestern Colorado. "That's the unfortunate case because it clouds the picture and builds unrealistic expectations," he says. Solix hopes to push its production capacity from its current rate of about 14,000 litres per hectare per year to between 37,000 and 47,000 litres per hectare per year. However, some start-ups have claimed that they can reach oil-production capacities

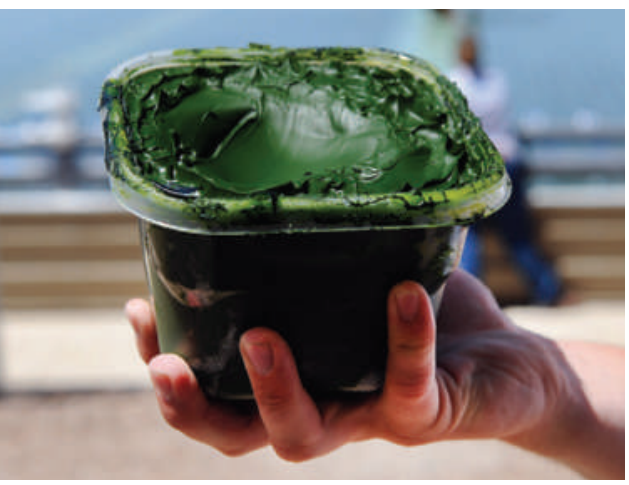

Fuel source of the future?

as high as 900,000 litres per hectare per year, which, says Henston, is "thermodynamically impossible".

Dillon, of Solazyme, says that the recent involvement by big-league investors, oil giants and the US military will help sort out approaches that are leading somewhere from those that aren't. "I think it's a good thing that we've got some real expectations coming on," he says. "There's been a lot of hype. That has a time window on it, and that type of time window tends to close when major players with real expectations start getting involved."

Amanda Leigh Mascarelli NEXT WEEK: CELLULOSIC ETHANOL

\section{Correction}

The Editorial 'Data's shameful neglect' (Nature 461,$145 ;$ 2009) stated that the Joint Information Systems Committee was established by the seven UK research councils. It was, in fact established by the three Higher Education Funding Councils. 